\title{
Integration of sustainable consumption education in the Malaysian School Curriculum: Opportunities and barriers
}

\author{
Yuek-Ming $\mathrm{Ho}^{1 \text { a }}$, Megat K.I. Kamaruddin ${ }^{1}$, and Anita Ismail ${ }^{1}$ \\ ${ }^{1}$ Faculty of Environmental Studies, Universiti Putra Malaysia, 43400 UPM Serdang, Selangor, \\ Malaysia
}

\begin{abstract}
It has been identified that gaps exist in education for sustainable development (ESD) in the Malaysian curriculum, and specifically in Education for Sustainable Consumption (ESC). There is a general lack of cohesiveness and intent although numerous aspects of education for sustainable consumption are present in the curriculum. On the conceptual level, the understanding of the vision of sustainable consumption based on sustainable human development is often vague or lacking. The opportunity to incorporate ESC in the curriculum could be realised in the impending curriculum review of the Malaysian secondary school curriculum. In 2011 Malaysia implemented the new Malaysian Standard Curriculum for Primary Schools and is now into its fifth year running. It will complete its first run by 2016 and will transition into the new Standard Curriculum for Secondary Schools that will be implemented in 2017. This curriculum revamp provides the opportunity for ESC content to be formally incorporated in the new Standard Curriculum for Secondary Schools. A study was carried out to determine the need and viability for the integration of sustainable consumption education in the Malaysian curriculum. The output from this study could inform the impending curriculum review for the inclusion of ESC content and materials in the new curriculum in 2017. A survey was carried out to identify opportunities and barriers towards this effort. The objective of this survey was to determine the barriers and enabling factors in the integration of Education for Sustainable Consumption (ESC) in learning and teaching among teachers. Preliminary findings showed that teachers are enthusiastic about integrating ESC in their learning and teaching, but lack formal training. The availability of trained teachers and administrative support system are also possible barriers to the implementation of the ESC curriculum. It is recommended that ESC content, stressing on desired behaviors towards sustainable consumption and production in daily life practices be integrated within the curriculum in the impending national curriculum review. Formal training of in-service and pre-service teachers are necessary for successful delivery of the curriculum.
\end{abstract}

\footnotetext{
a Corresponding author: yuekming@upm.edu.my
} 
Keywords. Education for Sustainable Consumption (ESC); Education for Sustainable Development (ESD); sustainability; curriculum integration.

\section{Introduction}

It has been identified that gaps exist in education for sustainable development (ESD) in the Malaysian curriculum, and specifically in Education for Sustainable Consumption (ESC) [3]. There is a general lack of cohesiveness and intent although numerous aspects of education for sustainable consumption are present in the curriculum. On the conceptual level, the understanding of the vision of sustainable consumption based on sustainable human development is often vague or lacking. In 2011 Malaysia implemented the new Malaysian Standard Curriculum for Primary Schools and is now into its fifth year running. It will complete its first run by 2016 and will transition into the new Standard Curriculum for Secondary Schools that will be implemented in 2017. The opportunity to incorporate ESC in the curriculum could be realised in the impending curriculum review of the Malaysian secondary school curriculum. This curriculum revamp provides the opportunity for ESC content to be formally incorporated in the new Standard Curriculum for Secondary Schools. A study was carried out to determine the need and viability for the integration of sustainable consumption education in the Malaysian curriculum. The output from this study could inform the impending curriculum review for the inclusion of ESC content and materials in the new curriculum in 2017. Suitable areas in the curriculum would be identified for the inclusion of appropriate ESC contents. The Malaysian secondary school curriculum and extra-curricular programmes were perused and suitable areas in the curriculum were identified for the inclusion of appropriate ESC contents. A survey was also carried out to identify opportunities and barriers towards this effort. The objective of this survey was to determine the barriers and enabling factors in the integration of Education for Sustainable Consumption (ESC) in learning and teaching among teachers. This paper presents the preliminary results from the survey.

\section{Nomenclature}

ESC Education for Sustainable Consumption

ESD Education for Sustainable Development

SCP Sustainable Consumption and Production

\subsection{From Malaysia's Vision 2020 to 'Green Vision 2030'}

Having reached the end of the Decade of Education for Sustainable Development (DESD, 2005-2014), it is timely yet to incorporate ESC as an agenda in the new Malaysian national curriculum. The main goal of DESD is to integrate values inherent in sustainable development into all aspects of learning to encourage changes in behavior that allow for a more sustainable and just society for all. The DESD recognises that achieving more sustainable consumption patterns requires both business practices and government policies that broaden the range of choices and guarantee clear and reliable information open to consumers to make environmentally and ethically sound decisions. Education plays a particularly important role in catalyzing this process. Malaysia is undergoing a process of fundamental reform to transform the nation into a high-income and developed nation by 2020. Based on this agenda, the Government has embarked on a number of national 
transformation programmes. These national policies have recognized the importance of promoting sustainable development. To achieve this, the Malaysian Government is strengthening its policy and institutional frameworks to bring about a switch to Sustainable Consumption and Production (SCP) patterns. The Government also recognises the importance of education in achieving these aims.

The rationale behind the inclusion of ESCP in the school curriculum is embedded in Malaysia's Green Vision. Malaysia aims to be a high-income fully developed nation, which is both inclusive and sustainable by 2020. This vision sees an enhanced standard of living, better quality of life and well-being of its people. Therefore, in order to meet its Vision 2020 holistically, Malaysia's growth needs to be 'green'. The 'Green Growth' approach is contextualised in terms of Malaysia's economic growth; using natural, human and capital resources in a sustainable manner to bring a better quality of life and continuous, inclusive and equitable economic growth for all, while avoiding pollution, minimising waste and hazardous products, avoiding inefficient use of natural resources, protecting biodiversity and ensuring security of supplies [1]. This vision to achieve a green growth scenario by 2030 (informally referred to as Green Vision 2030) takes into consideration the constraint of resources, environmental limits and social outcomes. In the green growth scenario, all resources are sustainably managed, climate change milestones met, and biodiversity and ecosystem services are protected, valued and restored [4]. Central to achieving green growth is the key principle of behavioural change. Building an informed and responsible society with sustainable consumption and production patterns and behaviour is necessary.

\subsection{Education for Sustainable Consumption (ESC)}

Education for Sustainable Consumption (ESC) combines education for sustainable development (ESD) and consumer education. The former focuses on the inter-relatedness among people, cultures and the ecosphere, while the latter highlights the rights and responsibilities of the consumer. Both ESD and ESC is about learning for change and learning to change [6]. While the inclusion of ESD themes into the school curriculum is a key condition for learning, it says little about the effectiveness of ESD programs or classroom teaching practices. Similarly, in ESC, many teaching and learning challenges remain. In addition, quality learning implies that the needs of individual learners are considered and addressed in developing and delivering lessons [7]. ESC pedagogies typically encourage teachers to shift their teaching away from traditional pedagogical approaches to the design of learning opportunities in which students are stimulated to ask questions, analyze, think critically and make decisions [5]. In teaching ESC, teachers are open to innovative pedagogical practices.

Obviously, the implementation of ESC programs and initiatives requires a variety of capacities. Policy makers, curriculum developers, school leaders, assessment experts, and most especially teachers, need a variety of resources and tools in relation to ESC. Funding, specifically the lack thereof, continues to be an overriding issue, all the more so in this era of economic downswings and budgetary cutbacks. For example, this might consist of critical government support for ESD-sensitive teacher training, in-service professional development and curriculum development. Therefore, it is necessary to assess the viability and factors that would affect the success of any curricular initiatives. Bearing these implementation issues in mind, this study was carried out to assess the response and opinion of teachers towards the integration of Education for Sustainable Consumption (ESC) in the school curriculum. 


\section{Methodology}

A preliminary survey was carried out to gather responses and opinion from secondary school teachers on the integration of ESC in teaching and learning. The survey questionnaire gathered teachers' feedback and opinion. A survey questionnaire was used in a preliminary survey to gather teachers' feedback and opinion on possible barriers and enabling factors that would inhibit or support the integration of ESC in teaching and learning. Based on convenience sampling, 48 teachers were chosen for the preliminary survey, their ages ranging from 23-57 years old, with teaching experiences ranging from one to 31 years (Table 1).

\section{Results and discussion}

Most teachers felt that it is necessary to integrate ESC in their subjects and would like to integrate ESC in their teaching. All the teachers surveyed felt that integration of ESC would benefit their students' learning (Table 2). They also agreed that integration of ESC would motivate them, and will enable them to apply a variety of learning and teaching methods.

When asked what would prevent them from integrating ESC in their teaching, a majority stated that they have no formal training in this field, and have no knowledge in carrying out ESC activities (Table 3). Other barriers quoted by the teachers included time constraint (43.75\%), heavy syllabus (31.25\%), lack of teaching aids (12.50\%), and workload $(10.42 \%)$.

The suggestions given by teachers to enable integration of ESC in learning and teaching were factors consistent with the removal of the barriers identified. $41.67 \%$ of the teachers quoted training for teachers as top priority, followed by availability of teaching aids (27.08\%) and time allocation for the subject (14.58\%). The teachers also asked for budget allocation, reduced class size and support by school administration (Table 4).

Table 1. Sociodemographic background of respondents

\begin{tabular}{lll}
\hline Sociodemographic Variables & $\mathrm{N}=48$ & Percent (n) \\
\hline Gender & Male & $25 \%(12)$ \\
& Female & $75 \%(36)$ \\
Age Range & Min. 23 years & \\
& Max. 57 years & \\
Teaching Experience & Min. 1 year & \\
& Max. 31 years & \\
Education Level & Diploma & $2.08 \%(1)$ \\
& Degree & $72.92 \%(35)$ \\
& Master & $20.83 \%(10)$ \\
Ethnicity & PhD & $4.17 \%(2)$ \\
& Malay & $75.00 \%(36)$ \\
& Chinese & $20.83 \%(10)$ \\
& Indian & $4.17 \%(2)$ \\
\hline
\end{tabular}


Table 2. Teachers' Opinion on Integration of ESC in Learning and Teaching

\begin{tabular}{lcc}
\hline \multicolumn{1}{c}{ Items } & $\begin{array}{c}\text { Yes } \\
(\%)\end{array}$ & $(\mathrm{n})$ \\
\hline $\begin{array}{l}\text { 1. Is it neccessary to integrate ESC in your } \\
\text { subject? }\end{array}$ & 95.83 & $(46)$ \\
$\begin{array}{l}\text { 2. Would you like to integrate ESC in your } \\
\text { teaching? }\end{array}$ & 95.83 & $(46)$ \\
$\begin{array}{l}\text { 3. Integration of ESC will benefit my } \\
\text { students' learning. }\end{array}$ & 100 & $(48)$ \\
$\begin{array}{l}\text { 4. Integration of ESC will motivate my } \\
\text { teaching. }\end{array}$ & 85.42 & $(41)$ \\
$\begin{array}{l}\text { 5. Will enable me to use a variety of Learning } \\
\text { \& Teaching methods. }\end{array}$ & 89.58 & $(43)$ \\
\hline
\end{tabular}

Table 3. Barriers to integration of ESCP in Learning and Teaching.

\begin{tabular}{lcc}
\hline $\begin{array}{l}\text { Unable to integrate ESCP in teaching } \\
\text { because: }\end{array}$ & $\begin{array}{c}\text { Agree } \\
(\%)\end{array}$ & (n) \\
\hline a. I have no formal training in ESCP & 89.58 & $(43)$ \\
b. I do not know how to carry out ESCP & 70.83 & $(34)$ \\
activities & & \\
$\begin{array}{l}\text { c. It is not an examination subject } \\
\text { d. Students are too busy with other academic }\end{array}$ & 79.17 & $(38)$ \\
activities & & $(38)$ \\
\hline
\end{tabular}

Table 4. Enabling Factors

\begin{tabular}{lcc}
\hline $\begin{array}{l}\text { Factors that will enable integration of ESCP in } \\
\text { L\&T }\end{array}$ & $\%$ & (n) \\
\hline 1. Traning for teachers & 41.67 & $(20)$ \\
2. Availability of teaching aids & 27.08 & $(13)$ \\
3. Time allocation & 14.58 & $(7)$ \\
4. Budget allocation & 6.25 & $(3)$ \\
5. Reduced class size & 4.17 & $(2)$ \\
6. Support by administration & 4.17 & $(2)$ \\
& & $\mathrm{N}=48$ \\
\hline
\end{tabular}

\section{Conclusion}

Preliminary findings from this study showed that teachers are enthusiastic about integrating ESCP in their learning and teaching, but lack formal training. The availability of trained teachers and administrative support system are also possible barriers to the implementation of the ESC curriculum. Capacity building, teaching resources and administrative support would enable teachers to integrate ESC in learning and teaching. It is recommended that ESCP content, stressing on desired behaviors towards sustainable consumption and production in daily life practices be integrated within the curriculum in the impending 
national curriculum review. Formal training of in-service and pre-service teachers are necessary for successful delivery of the curriculum.

\section{Acknowledgements}

This research was supported by Universiti Putra Malaysia's Research Grant and SCP Policy Support Malaysia.

\section{References}

1. Adham, K.N., Merle, K., \& Weihs, G (2013). Sustainable consumption and production in Malaysia: A baseline study of government policies, institutions and practices. EPU, Putrajaya, Malaysia.

2. Didham, R.J. (2011). The role of governments in education for sustainable consumption: strengthening capacity for effective implementation in China, Japan and the Republic of Korea. Didham, R.J.(Ed.) Institute for Global Environmental Strategies.

3. Habibah, L., \& Punitha, M. (2010). Environmental education: Current curriculum situational and the challenges at primary school, Malaysia. Procedia Social and Behavioral Sciences, 2, $1896-1900$.

4. OECD (2011). Towards green growth. OECD, Paris.

5. UNEP (2010). Here and now! education for sustainable consumption: Recommendations and guidelines. United Nations Environment Programme and the Marrakech Task Force on Education for Sustainable Consumption, in collaboration with Hedmark University College.

6. UNESCO (2011). Astrolabe: A guide to education for sustainable development coordination in asia and the pacific. UNESCO, Bangkok.

7. UNESCO (2012). Education for sustainable development sourcebook. Retrieved from http://unesdoc. unesco.org/images /0021/ 002163/216383.pdf. 